\title{
ONLINE IMPULSE BUYING WITH REFERENCE TO ONLINE GROCERY: A LITERATURE REVIEW
}

\author{
Abhishek Deokule \\ Assistant Professor, PTVA's Institute of Management, University of Mumbai, \\ Mumbai, Maharashtra, India \\ Dr. Hemant Katole
}

Associate Professor, Department of Management Sciences, Savitiribai Phule Pune University, Pune, Maharashtra, India

\begin{abstract}
Online Grocery Shopping is increasingly becoming more popular and one of the most preferred modes of buying grocery online. Online Grocery has become a major field of interest for researchers worldwide. With this every thriving market for online grocery shoppers comes a need to study various facets of Online Grocery Shopping. This review paper presents a preliminary move to understand the factors that affect online impulse buying and the urge to buy online grocery impulsively. The review paper takes cue from a host of empirical papers and review papers that present the online impulse buying phenomenon and tries to establish a correlation on whether the same factors that lead to impulse buying of accessories, clothes, books, etc. can be the factors affecting online impulse buying of grocery. Unlike impulse buying of the aforesaid products, impulse buying of grocery is majorly propelled by the advent of aesthetically designed websites or mobile applications, ease of use, discounts, offers, mood states. The review paper aims to pave the path for future researchers who would like to work in this unchartered area of impulse buying of online grocery.
\end{abstract}

Key words: Online Shopping, Impulse Buying, Online Grocery, Online Impulse Buying, Consumer Behavior, Indian Consumers

Cite this Article: Abhishek Deokule and Hemant Katole, Online Impulse Buying with Reference to Online Grocery: A Literature Review, International Journal of Management, 11(12), 2020, pp. 2832-2837.

http://iaeme.com/Home/issue/IJM?Volume $=11 \&$ Issue $=12$

\section{INTRODUCTION}

Grocery is the largest consumer segment by far; Indians spend more than $50 \%$ of their monthly income on groceries. It's a must-capture space for all retailers, be it offline or online. Grocery 
retail in India is estimated to be over $60 \%$ of the country's total retail market. Analysts peg it anywhere between $\$ 400$ billion to $\$ 600$ billion at present with the potential to cross $\$ 700$ billion by 2022 . Online grocery is still small, but analysts see it as having huge potential. It is estimated to be around $\$ 500$ million to a little over $\$ 1$ billion currently and expected to cross $\$ 3$ billion to $\$ 5$ billion or even much more over the next three to four years.

It's not just the size of the grocery pie that is attractive to e-tailers - it's the stickiness. Groceries (and vegetables and fruits) are an essential purchase for every household. They are bought frequently and with a high repeat rate. Customers typically buy them without giving too much thought. The player that can capture the lion's share of a customer's mind share and wallet share in groceries can have a sharp edge over others; it can become the default e-tailer for other purchases, too.

\section{LITERATURE REVIEW}

Impulse buying occurs when an individual makes an unintended, unreflective and immediate purchase whereas a planned purchase is characterized by deliberate, thoughtful search and evaluation that normally results in rational, accurate and better decisions (Halpern 1989; Johnson-Laird 1988). Contrary to a planned purchase, impulse buying is a spontaneous and immediate purchase (Fisher 1995) where the consumer is not actively looking for a product and has no prior plans to purchase (Beatty and Ferrell 1998). Beyond spontaneity, Rook (1987) further described impulse buying as an intense, exciting urge to buy without regard to the consequences of the purchase decision. Impulse buying behavior studies have attracted academic researcher attention because there appears to be a contradiction between what people say and what people do. While literature and consumers themselves claim that impulse buying behavior is normatively wrong, a substantial volume of purchases across a broad range of categories could be classified as impulsive (Cobb and Hoyer 1986; Han, Morgan, Kotsiopulos, and Kang-Park 1991; R.J. Fisher. 1995).

The importance of understanding impulse purchasing in retail stores was first identified in the marketing literature over fifty years ago (Clover 1950). The classification of a purchase as planned or impulse began with Stern (1962) study where he provided the basic framework of impulse buying by categorizing a buying behavior as planned, unplanned, or impulse. Planned purchases involve time-consuming information-searching with rational decision making, whereas unplanned buying refers to all shopping decisions made without any advance planning. Impulse buying is distinguished from the unplanned buying in terms of quick decision making.

Stern (1962) delineated four distinct types of impulse buying: pure, reminder, suggestion, and planned impulse buying:

- Pure impulse buying: is a novelty or escape purchase which breaks a normal buying pattern

- Reminder impulse buying: occurs when a shopper sees an item or recalls an advertisement or other information and remembers that the stock at home is low or exhausted

- Suggestion impulse buying: occurs when a shopper sees a product for the first time and visualizes a need for it, and

- Planned impulse buying: takes place when the shopper makes specific purchase decisions on the basis of price specials, coupon offers and the like.

Iyer (1989) further distinguished that all impulse purchases are unplanned, but unplanned purchases are not always impulsively decided.

Han et al. (1991) modified the Stern (1962) classification of impulse mix in context of fashion products and developed as four types of impulse buying: 
- Planned impulse buying

- Reminded impulse buying

- Suggestion or fashion-oriented impulse buying

- Pure impulse buying

Planned impulse buying is partially planned but specific product or categories are not decided by the shopper. They are further determined on the basis of the different sales promotions inside the shop. Reminder impulse buying occurs when the buyer is reminded of the need of the product noticing it in the shop. Han et.al, (1991) described fashion oriented impulse as a type of suggestion impulse where the purchase is motivated by self-suggestion to buy the new fashion product. In case of fashion oriented impulse buying, shopper has no previous experience with the new and fashionable product. Mattila and Enz (2002) later argued that fashion-oriented impulse buying can be influenced by shopper's own positive emotions when shopping.

Research on impulse buying has been based on varying conceptual definitions of the construct and has focused primarily on in-store retailing. With the prominence of online retailing it would seem appropriate to expand the concept of impulse purchasing to accurately capture impulse purchasing behavior online.

Understanding of impulse purchasing is further accentuated by the prevalence of online retailing, an easily available mode for making impulse purchases. Online retailing eliminates the constraints of time and space that often face shoppers (Kalakota and Whinston 1997; Eroglu, Machleit, and Davis 2001). Recently, Donthu and Garcia (1999) profiled Internet shoppers and found that Internet shoppers are more impulsive than in-store shoppers. However, consumer behavior on the Internet is not well understood (Sultan 2002).

The descriptions of impulse buying before the study of Rook (1987) were focused on the product while determining an impulse purchase. The earlier studies did not include the consumer and his personal traits as the factor influencing impulse purchases. Rook (1987) argued that during impulse buying, the consumer experiences an instantaneous, overpowering and persistent desire. He characterised the impulse buying as unintended, non-reflective reaction, which occurs soon after being exposed to stimuli inside the store.

Rook and Gardner (1993) defined impulse buying as an unplanned behavior involving quick decision-making and tendency for immediate acquisition of the product. Beatty and Ferrell (1998) described that Impulse buying refers to immediate purchases which are without any

Pre-shopping objective either to purchase the specific product category or to fulfil a specific need. They explained that the impulse buying behavior occurs after experiencing a buying desire by the shopper and without much reflection. The buying of an item which is out-of-stock and reminded during encountering the product are excluded from the purview of impulse buying.

Bayley and Nancarrow (1998) defined impulse buying as a "sudden, compelling, hedonically complex buying behavior in which the rapidity of an impulse decision process precludes thoughtful and deliberate consideration of alternative information and choices." Hedonic behavior is marked with pleasure; in contrast to the utilitarian behavior where the shoppers seek for functional benefits and economic value in the shopping process.

Block and Morwitz (1999) enunciated the definition of impulse purchase as consumer buying an item with little or no deliberation after the result of a sudden, powerful urge. Kacen and Lee (2002) stated that impulsive behavior are more arousing and irresistible but less deliberative when compared to planned purchasing behavior. According to Engel and Blackwell (1982) impulse buying is an action undertaken without previously having been 
consciously recognised or a buying intention formed prior to entering the store. Based upon the different description, we conclude that impulse buying involves hedonic purchase decisions which are made inside a store and excludes the reminder purchasing activities.

Applebaum (1951) introduced the notion of exposure to stimulus into the concept of impulse buying, and defined impulse buying as "buying that presumably was not planned by the customer before entering a store, but which resulted from a stimulus created by a sales promotional device in the store".

Over time, researchers began to look at consumer characteristics rather than product characteristics or stimuli as it was agreed that impulse purchasing is not confined to any particular product or product category (Rook 1987).

Rook and Gardner (1993) undertook an exploratory study of the mood antecedents of impulse buying and proposed that each of the three basic mood dimensions (pleasure, arousal, and dominance) is associated with a primary core theme that either supports or dissuades consumer's buying impulses. Pleasurable moods range from positive to negative and can either motivate or demotivate a buying impulse (Rook and Gardner1993). Similarly, Beatty and Ferrell (1998) argue positive affect is related to in-store browsing, examining a retailer's merchandise for recreational and/or informational purposes without an immediate intent to buy. Furthermore, impulse buying has been related to hedonic motivations, such as fun, novelty and surprise (Hausman 2000). Psychological theory and research has long considered "impulsiveness" to be a personality trait (Freud 1949; Goldenson 1984).

Rao \& Laverie (2004) suggest that impulse purchases exist on the Internet and there are stimuli other than the product that can cause the eventual impulse purchases. Their research supports that both in-store browsing and mood states influence impulse purchases on the Internet. Yet, perceptions of quality and experience with the product are not as realistic online.

Childers et al. (2001) suggest, if shoppers believe that the sensory information available via the interactive media is sufficient, there is reason to believe that the shoppers will enjoy using the new media for web-shopping. "Webmosphirics" according to Childers et al. (2001) represents the virtual environment counterpart to the physical surroundings associated with the retail atmosphere (such as Graphics, text, pop-up windows, search engine configuration, audio, color, streaming video, and organization and grouping of merchandise), may lead to impulse buying.

Ramus and Nielsen (2005) enumerate that online shoppers perceive internet grocery shopping an advantage when compared to conventional grocery shopping in terms of convenience, product range and price. Disadvantages, which could act as mental barriers, are, for instance, the risk of receiving inferior quality groceries and the loss of the recreational aspect of grocery shopping. Morganosky and Cude (2000) reported convenience and saving time as the primary reasons for buying groceries online but cited physical or constraint issues that made it difficult for grocery shoppers to shop at grocery stores.

\section{DISCUSSIONS}

The review suggests that buying impulsively online or the urge consumers get to buy online are two elements that lead to actual buying of grocery. The parameters that entail within these elements are hedonism in terms of pleasure one derives to buy online, apart from the atmosphere of the website, its layout, the security features, privacy of the transactions, the trust factor that consumers gain after repeated purchases apart from discounts and promotional offer $\mathrm{s}$ that need to be studied more. Online Impulse Buying of Grocery Products is a phenomenon that is yet to be explored more in terms of the factors that propel consumers to buy online. Though online grocery shopping has been rampant in the past 5 years in India, eliciting accurate information would require more detailed quantitative study. 


\section{CONCLUSION}

They are bought frequently and with a high repeat rate. Customers typically buy them without giving too much thought. The player that can capture the lion's share of a customer's mind share and wallet share in groceries can have a sharp edge over others; it can become the default e-tailer for other purchases, too.

The parameters that entail within these elements are hedonism in terms of pleasure one derives to buy online, apart from the atmosphere of the website, its layout, the security features, privacy of the transactions, the trust factor that consumers gain after repeated purchases apart from discounts and promotional offer $\mathrm{s}$ that need to be studied more. Online Impulse Buying of Grocery Products is a phenomenon that is yet to be explored more in terms of the factors that propel consumers to buy online. Though online grocery shopping has been rampant in the past 5 years in India, eliciting accurate information would require more detailed quantitative study.

\section{REFERENCES}

[1] Applebaum, W. (1951), "Studying Consumer Behavior in Retail Stores", Journal of Marketing, Vol. 16, October, pp. 172-178.

[2] Bayley, G., \& Nancarrow, C. (1998). Impulse Purchasing: A Qualitative Exploration of the Phenomenon. Qualitative Market Research: An International Journal, 1(2), 99-114.

[3] Beatty, S. E. and Ferrell M. E. (1998), "Impulsive Buying: Modeling Its Precursors", Journal of Retailing, Vol. 74 No.2, pp. 169-191.

[4] Childers, T.L., Carr C.L., Peck J., and Carson S. (2001), "Hedonic and utilitarian motivations for online retail shopping behavior", Journal of Retailing, Vol. 77, 2001, pp.511-535.

[5] Clover, V. T. (1950), "Relative Importance of Impulse Buying in Retail Stores", Journal of Marketing, Vol. 25, July, pp. 66-70.

[6] Cobb, C. J. and Hoyer W. D. (1986), "Planned Versus Impulse Purchase Behavior", Journal of Retailing, Vol. 62, Winter, pp. 67-81.

[7] Donthu, N. and Garcia A. (1999), “The Internet Shopper”, Journal of Advertising Research, 1999, pp. 52-58.

[8] Engel, J., \& Blackwell, R. (1982). Consumer Behavior. Chicago: Dryden Press.

[9] Eroglu, S. A., Machleit K. A., Davis L. M. (2001), “Atmospheric Qualities of Online Retailing: A Conceptual Model and Implications," Journal of Business Research, November, Vol. 54 Issue 2, pp.177-184.

[10] Freud, S. (1920/1949), “Aspects of Development and Regression”, A General Introduction to Psychoanalysis, New York: Perma Giants, pp. 297-312.

[11] Gardner, M.P., and Rook D. (1988). "Effects of Impulse Purchases on Consumers' Affective States", in Advances in Consumer Research, Vol. XV, Ed. M. Houston, Provo, UT: Association for Consumer Research, pp. 127-130.

[12] Goldenson, R.M. (1984), Longman Dictionary of Psychology and Psychiatry, New York: Longman. Gutierrez, B. P. B. (2004). Determinants of planned and impulse buying: The case of the Philippines. Asia Pacific management review, 9(6), 1061-1078. 
[13] Halpern, D.F. 1989. Thought and Knowledge: An Introduction to Critical Thinking, 2nd ed. Erlbaum Publishing, Hillsdale, NJ. Han, Y. K., Morgan G. A., Kotsiopulos A., and Komg-Park J.(1991), "Impulse Buying Behavior of Apparel Purchasers", Clothing and Textiles Research Journal, Vol. 9, Spring, pp. 15-21.

[14] Hausman, A. (2000), "A multi-method investigation of consumer motivations in impulse buying behavior", Journal of Consumer Marketing, Vol.17 No.5, pp. 403-417.

[15] Iyer, E. S. (1989), Unplanned purchasing: Knowledge of shopping environment and time pressure. Journal of Retailing, 65(1), 40-57.

[16] Johnson-Laird, P.N. 1988. “A taxonomy of thinking”, Sternberg, R.J.,E.E. Smith. (Eds.). The Psychology of Human Thought, Cambridge University Press, Cambridge, MA, 429-457.

[17] Madhavaram, S.R., Laverie, D.A. (2004), "Exploring Impulse Purchasing on the Internet,"Advances in Consumer Research, Vol.31, pp.59-66.

[18] Mattila ,A. S., \& Enz, C. A. (2002). "The Role of Emotions In Service Encounters," Journal of Service Research, 4(4), 268-77.

[19] Michelle A. Morganosky, Brenda J. Cude, (2000) "Consumer response to online grocery shopping", International Journal of Retail \& Distribution Management, Vol. 28 Iss: 1, pp.17 26.

[20] Muruganantham, G. and Bhakat, R.S. (2013), “An Empirical Study of Impulse Buying Behavior in Online Bookstores,” International Journal of Marketing Studies Vol. 5, No. 3.

[21] Ramus, K. and Nielsen, N. A. (2005). Online grocery retailing: What do consumers think? Internet Research, 15(3), 335-352.

[22] Rook, D. W. (1987), “The Buying Impulse”, Journal of Consumer Research, Vol.14, September, pp. 189-199.

[23] Rook, D. W. and Fisher R. J. (1995), "Normative Influences on Impulsive Buying Behavior", Journal of Consumer Research, Vol. 22, December, pp. 305-313.

[24] Stern, H. (1962), “The Significance of Impulse Buying Today”, Journal of Marketing, Vol. 26, April, pp. 59-63.

[25] Sultan, F. (2002), "Consumer response to the Internet: an exploratory tracking study of on-line home users," Journal of Business Research, Vol. 55, pp. 655-663. 